\title{
CALORIC RESTRICTION DIET (CR DIET) OR MEDITERRAMEAN DIET (MD) - WHICH IS THE BEST CHOICE FOR FORMER ATHLETES?
}

\author{
Maja Czerwińska, , B, D Joanna Hołowko,, B Dominika Maciejewska,, c \\ Paweł Wysokiński, , B Krzysztof Ficek, ,2, B Paweł Wilk, ${ }^{3, \text { B }}$ Ewa Stachowska, A, D, E \\ 1 Department of Biochemistry and Human Nutrition, Pomeranian Medical University, Szczecin, Poland \\ 2 Department of Physiotherapy, Faculty of Physical Education and Health Promotion, University of Szczecin, Szczecin, Poland \\ ${ }^{3}$ Department of Individual Sports, Faculty of Physical Education and Health Promotion, University of Szczecin, Szczecin, Poland

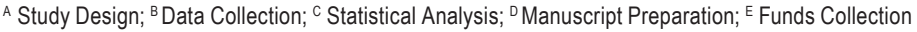

\author{
Address for correspondence: \\ Maja Czerwińska \\ Pomeranian Medical University \\ Department of Biochemistry and Human Nutrition \\ Broniewskiego 24, 71-460 Szczecin, Poland \\ E-mail: majaczerwinska89@gmail.com
}

\begin{abstract}
Ahstract. Overweight or obesity which often develop in athletes who end their careers is one of the most important issues of the world of sport. During aging, an increase in the amount of intra-abdominal fat is observed; this fat increases the risk of such metabolic disease as diabetes or hypertension.

The participants of the study were 94 males. The people were randomly assigned to one of 2 groups: group 1 - people using the diet based on calorie restriction CRON $(n=32)$, and group 2 - those who followed the recommendations of the Mediterranean diet $(n=34)$. The patients who at the check-up declared not following any diet were assigned to the control group $(n=28)$.

A change in parameters was observed in each of the sub-groups after the intervention. The most significant changes were observed in the sub-group which lost $>2.6 \mathrm{~kg}$.

Both the diet based on mild calorie restriction and the Mediterranean diet had positive effect on the change of the former athlete's body parameters after the 6 -week long dietary intervention. Both diets which were being tested changed the body composition of the athletes who ended their careers in a similar way.
\end{abstract}

Key WOrdl: caloric restriction, CRON diet, Mediterranean diet

\section{Introduction}

Overweight or obesity which often develop in athletes who end their careers are important issues of the world of sport. A typical problem is the decrease in the muscle mass accompanied by an increase in the proportion and a change in the localization of fat tissue (Jaskólski, Jaskólska, 2006).

During aging, an increase in the amount of intra-abdominal fat is observed; this fat increases the risk of such metabolic disease as diabetes, hypertension or circulatory diseases (O'Kane, Teitz, Fontana, Lind, 2002). It seems 
that majority of athletes start gaining weight within 15-30 years after the conclusion of sporting careers (Pihl, Jürimäe, 2001). The average increase in the BMI (Body Mass Index) among footballers was $2.4 \mathrm{~kg} / \mathrm{m}^{2}$ since the end of their career. In the tested group, $78 \%$ of those surveyed were found to be overweight, whereas $4 \%$ - obese (Arliani et al., 2014). In other studies it was demonstrated that the percentage of overweight athletes was as high as $35 \%$ and with obesity - 3\% (Marquet et al., 2013). The increase in the body weight of former athletes is related to the increase in the risk of circulatory diseases (Pihl, Jürimäe, 2001).

Despite those findings, it seems that the former athletes face a risk of diet-related diseases which is still lower than for the rest of the population (Kerr, DeFreese, Marshall, 2014). Lower incidence of these diseases may be related to their lifestyle (Batista, Soares, 2013). Also the results of Polish studies are similar to the ones described above. After examining 90 obese former athletes, it was found that they suffered from diabetes less often and had smaller waist lines than their obese peers. Additionally, in the group of the most obese former athletes $\left(\mathrm{BMl}>40 \mathrm{~kg} / \mathrm{m}^{2}\right.$ ) hypertension was less frequent and the period of obesity was shorter (Szczawińska, Ponikowska, Chojnowski, Grabowska, 2006).

Scientists think that the caloric restriction (CR) diets, also known as CRON diets (Calorie Restriction with Optimal Nutrition), which mean consuming a lower amount of calories than the body's demand may be one of the methods of extending lifespan Until now, only a few studies have been made which examined the influence of caloric restriction on humans (Heilbronn, Ravussin, 2003).

The Mediterranean diet is characterized by inclusion of vegetables and little participation of processed products. The main source of fats in this diet is olive oil. A characteristic feature of this diet is the daily consumption of small or moderate amounts of dairy and red wine. An inseparable element of this diet is also daily, moderate physical activity (Przysławski, 2007).

\section{Purpose}

The problem of the increasing body weight of former athletes still has not been solved. The aim of this study is to compare the impact of the CRON diet and the Mediterranean diet on the body composition of persons who have ended their sporting careers. The object of the study is the comparison of the body weight parameter changes in patients before the introduction of the diet and after completion thereof. The research challenge is to answer the question whether a diet based on mild caloric restrictions has a better influence on the improvement of the body composition in the group of former athletes using the diet for 6 weeks as compared to the Mediterranean diet. Establishing which diet has a better impact will allow for creation of algorithms of behaviour for people after ending their sporting careers. Achieving this aim will allow them to reduce overweight and obesity in this group and to improve their health.

\section{Methods}

The participants of the study were 94 males of the Caucasian race, aged 20-57, who volunteered to take part in the project "CRON diet as an alternative for athletes ending their sporting career" which was carried out in the Department of Biochemistry and Human Nutrition of the Pomeranian Medical University in Szczecin. All persons belonged to the group of different sport disciplines former athletes and the period which elapsed since the end of their sporting careers until accession to the study did not exceed 5 years. Each participant expressed in writing their consent to take part in the project. 
The people who participated in the study were randomly assigned to one of 2 groups: group 1 - people using the diet based on calorie restriction CRON $(n=32)$, and group 2 - those who followed the recommendations of the Mediterranean diet $(n=34)$. The patients who at the check-up declared not following any diet were assigned to the control group $(n=28)$.
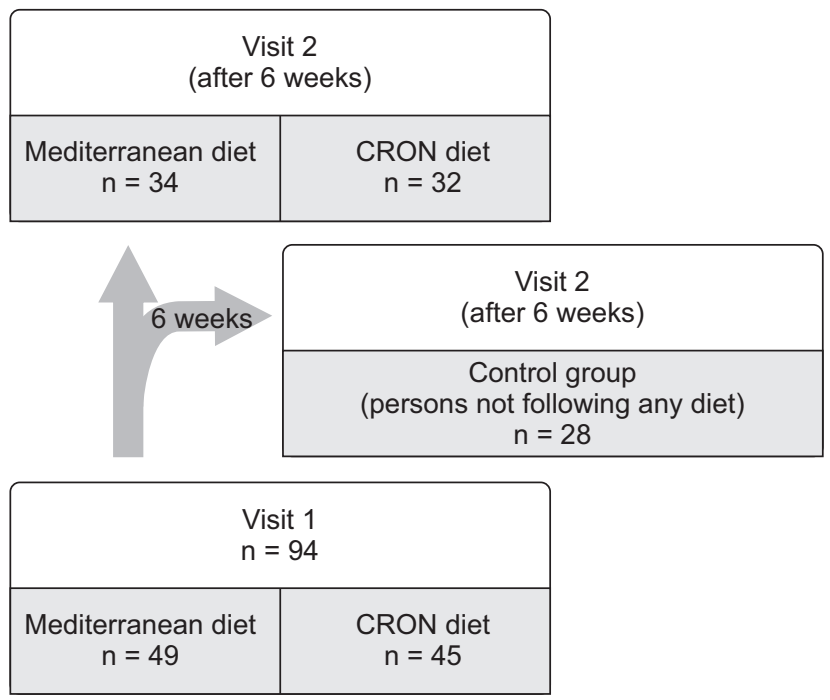

Figure 2. Scheme of the study

The criteria which excluded participants from the study were the following: high level of physical activity, hypercholesterolaemia (cholesterol concentration $>0.8 \mathrm{mM}$ or treated dyslipidaemia), diabetes (glucose concentration $>126 \mathrm{mg} / \mathrm{dl}$ or treated diabetes), arterial hypertension (systolic pressure $>140 \mathrm{~mm} \mathrm{Hg}$ or diastolic $>90 \mathrm{~mm} \mathrm{Hg}$ or treated hypertension), co-occurrence of food allergies, celiac disease or other bowel diseases, vegetarianism or conditions requiring special diets, alcoholism or drug addiction.

\section{Anthropometric measurements}

During every check-up, the patient underwent several anthropometric measurements: body weight and height, waist line, hip circumference, left arm circumference, skinfold thickness measurement below the lower tip of the left shoulder blade and above the iliac crest, and also the skinfold thickness measurement over the triceps and biceps on the left arm.

To measure the body weight RADWAG scales was used (model WPT 100/200 OW) which also had a height measuring mechanism; the result of the measurement of the body weight was in kilograms ( $0.1 \mathrm{~kg}$ precision) while the height in $\mathrm{cm}(0.5 \mathrm{~cm}$ precision). The circumferences of the waist, hips and arm were measured with an nonexpandable anthropometric measuring tape $(0.1 \mathrm{~cm}$ precision). The waist circumference was measured halfway between the lower extent of the ribs and the upper tip of the iliac bone, while the hip measurement was taken 
where it was the largest. Each measurement was performed twice and the results were averaged. The thickness of skinfolds was measured with a Saehan caliper. Measurements were made three times and the results were averaged.

The patients also underwent measurements of BMR (basal metabolic rate) and their body composition was measured with the BIA (Bioelectrical Impedance Analysis), Cosmed device.

\section{Estimate of calorie demand}

Total metabolic rate (TMR) was calculated on the basis of BMR and a physical activity co-efficient. The level of physical activity was established using long version of International Physical Activity Questionnaire (IPAQ). On the basis of results participants were assigned to one of 3 categories:

- "High - to this category belong athletes who meet one of the criteria:

- 3 or more days of intensive physical activity, a total of at least 1,500 MET-min/week,

- 7 or more days of any combination of activity (walking, moderate or intensive activity) exceeding 3,000 MET-min/week.

- Moderate - includes athletes who meet 1 of 3 criteria:

- 3 or more days of intensive physical activity, at least 20 minutes per day,

- 5 or more days of moderate activity, at least 30 minutes per day,

- 5 or more days of any combination of activity (walking, moderate or intensive activity) exceeding 600 MET-min/week.

- Insufficient - includes athletes who did not do any physical activity or did not meet the criteria for a level moderate or high" (Sławecki, 2012).

\section{Diet introduction}

The study used 2 types of diets: CRON and Mediterranean diet. Their characteristics are presented below (Table 1).

Table 1. CRON diet and Mediterranean diet characteristics

CRON diet Mediterranean diet

\begin{tabular}{lcc}
\hline Total calorie content of the diet & $\begin{array}{c}\text { Standard calorie intake or reduction by } 500 \mathrm{kcal} \\
\text { compared to TMR }\end{array}$ & $\begin{array}{c}\text { Reduced by } 30 \% \text { in relation to BMR } \\
\text { (on average reduced by } 806 \mathrm{kcal} \text { ) }\end{array}$ \\
\hline Proteins & $1 \mathrm{~g} / \mathrm{kg}$ of body weight & $1 \mathrm{~g} / \mathrm{kg}$ of body weight \\
\hline Fats, including & $<20 \%$ of TMR demand & $30-35 \%$ of TMR demand \\
SFA & $<7 \%$ & $<10 \%$ \\
MUFA & $>20 \%$ & $>60 \%$ \\
PUFA & $>30 \%$ & $>20 \%$ \\
\hline Cholesterol & $200 \mathrm{mg} /$ day & $200-300 \mathrm{mg} / \mathrm{day}$ \\
\hline Carbohydrates & $50-60 \%$ of TMR demand & $50-60 \%$ of TMR demand \\
\hline Amount of fish per week & 2 times & 3 times \\
\hline Afternoon snacks & Fruit and natural yoghurts & Fruit and nuts \\
\hline
\end{tabular}




\section{Nutrition diapy}

In order to verify whether patients adhered to the recommendation, they ran a nutrition diary, in which they noted what, in what amounts, at what time they ate and drank during the two days before the control visits. All diaries were checked by a dietician and the weight of the products was adjusted on the basis of photo album of products and dishes, published by the Food and Nutrition Institute, 2000.

\section{Statistical analysis}

All statistical analyses were performed using the statistical R package (version 3.0.1,16 May 2013). Since the obtained results corresponded with normal distribution, the T-student test was used in statistical analysis. The level of relevance was accepted as $p<0.05$.

\section{Results}

In the CRON group, 31 participants had moderate level of physical activity (1 participant had insufficient level of physical activity) and in Mediterranean diet 34 participants had moderate level of physical activity.

The characteristics of both groups at the time of accession to the study are presented in Tables 2 and 3.

Table 2. Characteristics of the CRON group before the dietary intervention

\begin{tabular}{|c|c|c|c|c|c|}
\hline Variable & Arithmetic average & Standard Deviation & Median & Min. & Max. \\
\hline Body weight [kg] & 89.80 & 12.98 & 86.70 & 69.00 & 118.80 \\
\hline Thickness of the skinfold over the triceps [mm] & 13.40 & 5.45 & 11.50 & 5.00 & 29.00 \\
\hline Thickness of the skinfold over the biceps [mm] & 10.10 & 5.21 & 8.80 & 2.00 & 23.00 \\
\hline Thickness of the skinfold under the shoulder blade [mm] & 20.10 & 6.74 & 19.00 & 10.00 & 38.70 \\
\hline Thickness of the skinfold over the hip [mm] & 19.50 & 7.12 & 19.00 & 7.50 & 38.70 \\
\hline Upper arm circumference [cm] & 33.80 & 3.17 & 34.40 & 25.50 & 41.00 \\
\hline Waist circumference [cm] & 94.00 & 13.75 & 102.00 & 23.80 & 117.00 \\
\hline Hip circumference [cm] & 100.30 & 13.75 & 102.00 & 23.80 & 117.00 \\
\hline BMI [kg/m²] & 28.00 & 4.05 & 27.30 & 21.80 & 39.20 \\
\hline Fat tissue $[\mathrm{kg}]$ & 27.00 & 9.02 & 26.40 & 10.80 & 46.60 \\
\hline Fat tissue [\%] & 28.94 & 6.52 & 30.20 & 5.00 & 39.30 \\
\hline Lean body mass [kg] & 62.50 & 6.85 & 61.00 & 50.80 & 76.10 \\
\hline Muscle mass [kg] & 44.00 & 5.52 & 43.10 & 34.30 & 60.2 \\
\hline $\mathrm{BCM}[\mathrm{kg}]$ & 36.48 & 4.95 & 36.10 & 29.80 & 50.70 \\
\hline Total water in the body [kg] & 46.61 & 4.95 & 45.20 & 38.20 & 55.70 \\
\hline Extracellular water [kg] & 19.74 & 2.75 & 19.30 & 14.20 & 24.80 \\
\hline Intracellular water [kg] & 26.87 & 3.38 & 26.40 & 22.70 & 36.30 \\
\hline
\end{tabular}

In the CRON diet group a higher body weight was observed $(88.80 \pm 12.98 \mathrm{~kg}$ VS $87.80 \pm 13.73 \mathrm{~kg})$, larger waist circumference $(94.00 \pm 13.75 \mathrm{~cm}$ vs $91.70 \pm 14.67 \mathrm{~cm})$ and higher content of fat tissue $(27.00 \pm 9.02$ vs 25.30 $\pm 10.18)$. In comparison with the Mediterranean group, the patients from the CRON diet group also manifested a higher muscle mass ( $44.00 \pm 5.52 \mathrm{~kg}$ vs $42.40 \pm 6.21 \mathrm{~kg}$ ) and higher body cell mass BCM (36.48 $\pm 4.95 \mathrm{vs} 35.19$ $\pm 4.26)$. 
Table 3. Characteristics of the Mediterranean diet group before the dietary intervention

\begin{tabular}{|c|c|c|c|c|c|}
\hline Variable & Arithmetic average & Standard deviation & Median & Min. & Max. \\
\hline Body weight [kg] & 87.80 & 13.73 & 86.90 & 60.50 & 122.10 \\
\hline Thickness of the skinfold over the triceps [mm] & 13.60 & 5.58 & 13.00 & 5.00 & 29.80 \\
\hline Thickness of the skinfold over the biceps [mm] & 10.40 & 5.22 & 9.30 & 2.00 & 24.70 \\
\hline Thickness of the skinfold under the shoulder blade [mm] & 19.10 & 6.78 & 19.00 & 4.00 & 35.00 \\
\hline Thickness of the skinfold over the hip [mm] & 20.80 & 7.45 & 20.00 & 8.00 & 39.00 \\
\hline Upper arm circumference $[\mathrm{cm}]$ & 33.30 & 6.30 & 32.50 & 17.50 & 62.30 \\
\hline Waist circumference $[\mathrm{cm}]$ & 91.70 & 14.67 & 92.80 & 16.00 & 115.50 \\
\hline Hip circumference [cm] & 99.50 & 8.56 & 101.50 & 56.50 & 110.50 \\
\hline BMI [kg/m²] & 27.40 & 4.00 & 26.80 & 19.20 & 38.40 \\
\hline Fat tissue mass [kg] & 25.30 & 10.18 & 26.10 & 3.20 & 42.90 \\
\hline Fat tissue mass [\%] & 28.13 & 8.75 & 29.20 & 3.40 & 40.90 \\
\hline Lean body mass [kg] & 61.10 & 7.76 & 61.00 & 43.30 & 79.20 \\
\hline Muscle mass [kg] & 42.40 & 6.21 & 42.30 & 29.20 & 56.30 \\
\hline $\mathrm{BCM}[\mathrm{kg}]$ & 35.19 & 4.26 & 35.50 & 24.80 & 44.10 \\
\hline Total water in the body [kg] & 45.24 & 4.73 & 45.50 & 34.60 & 56.60 \\
\hline Extracellular water [kg] & 19.16 & 2.72 & 19.00 & 14.70 & 24.40 \\
\hline Intracellular water [kg] & 25.64 & 3.52 & 26.10 & 15.20 & 32.40 \\
\hline
\end{tabular}

In neither of the groups a BMI $>40 \mathrm{~kg} / \mathrm{m}^{2}$ was observed. $25 \%$ of patients from group Mediterranean diet group had proper body weight, and $22 \%$ of the people in the CRON diet group. In both groups most people had BMI indicating overweight ( $57 \%$ vs $56 \%$ ).

Results of the patients from both groups were further divided into 3 sub-groups: a sub-group of patients who reduced their body weight by up to $1.4 \mathrm{~kg}$ ( $n=15 \mathrm{in} \mathrm{CRON} \mathrm{group,} \mathrm{and} n=15$ in Mediterranean group); a sub-group of patients who lost between 1.5-2.4 kg ( $n=10$ in CRON group and $n=11$ in Mediterranean group); and a sub-group of persons, who during the dietary intervention lost more than $2.4 \mathrm{~kg}(n=7$ in CRON group and $n=8$ in Mediterranean group). The results of each of the subgroups are shown in the Table 4.

Tahle 4. Changes in patients from both groups, those who lost up to $1.4 \mathrm{~kg}$

\begin{tabular}{|c|c|c|c|c|}
\hline \multirow{2}{*}{ Intervention } & \multicolumn{2}{|c|}{ CRON } & \multicolumn{2}{|c|}{ Mediterranean } \\
\hline & Average \pm SD & $\mathrm{P}$ & Average \pm SD & $\mathrm{P}$ \\
\hline 1 & 2 & 3 & 4 & 5 \\
\hline BMI & $28.5 \pm 1.3$ & & $28.8 \pm 8.5$ & \\
\hline BMI after 6 weeks & $27.0 \pm 17.8$ & $p<0.05$ & $28.2 \pm 14.2$ & $P<0.004$ \\
\hline Thickness of the skinfold over the triceps & $15.4 \pm 5.3$ & & $13.0 \pm 6.1$ & \\
\hline Thickness of the skinfold over triceps after 6 weeks & $14.0 \pm 7.0$ & NS & $13.1 \pm 5.1$ & NS \\
\hline Thickness of the skinfold over biceps & $14.3 \pm 6.3$ & & $12.0 \pm 4.3$ & \\
\hline Thickness of the skinfold over biceps after 6 weeks & $14.8 \pm 6.2$ & NS & $12.0 \pm 5.7$ & NS \\
\hline Thickness of the skinfold below the shoulder blade & $24.9 \pm 5.7$ & & $22.7 \pm 9.1$ & \\
\hline Thickness of the skinfold below shoulder blade after 6 weeks & $22.8 \pm 6.2$ & NS & $20.4 \pm 7.4$ & NS \\
\hline Thickness of the skinfold over the hip & $22.8 \pm 8.4$ & & $23.7 \pm 7.2$ & \\
\hline Thickness of the skinfold over hip after 6 weeks & $21.5 \pm 5.6$ & NS & $19.8 \pm 5.0$ & $P<0.05$ \\
\hline
\end{tabular}




\begin{tabular}{|c|c|c|c|c|}
\hline 1 & 2 & 3 & 4 & 5 \\
\hline Upper arm circumference & $34.6 \pm 2.9$ & & $35.2 \pm 4.3$ & \\
\hline Upper arm circumference after 6 weeks & $34.7 \pm 1.8$ & NS & $34.7 \pm 4.1$ & NS \\
\hline Waist circumference & $99.7 \pm 8.0$ & & $98.8 \pm 9.0$ & \\
\hline Waist circumference after 6 weeks & $97.8 \pm 7.4$ & NS & $95.3 \pm 0.8$ & $P<0.015$ \\
\hline Hip circumference & $100.0 \pm 24.5$ & & $103.7 \pm 4.9$ & \\
\hline Hip circumference after 6 weeks & $105.2 \pm 3.7$ & NS & $98.2 \pm 12.4$ & NS \\
\hline Fat mass $\mathrm{kg}$ & $31.4 \pm 8.9$ & & $33.3 \pm 6.4$ & \\
\hline Fat mass $\mathrm{kg}$ after 6 weeks & $31.7 \pm 6.2$ & NS & $29.9 \pm 9.1$ & NS \\
\hline Fat mass $\%$ & $32.1 \pm 7.1$ & & $34.0 \pm 3.1$ & \\
\hline Fat mass $\%$ after 6 weeks & $33.9 \pm 4.4$ & NS & $31.4 \pm 5.7$ & NS \\
\hline Lean body mass $\mathrm{kg}$ & $65.6 \pm 7.7$ & & $64.3 \pm 8.1$ & \\
\hline Lean body mass after 6 weeks & $61.6 \pm 7.4$ & NS & $63.7 \pm 5.8$ & NS \\
\hline BCM kg & $37.6 \pm 5.8$ & & $37.1 \pm 5.2$ & \\
\hline BCM kg after 6 weeks & $35.2 \pm 4.3$ & NS & $38.5 \pm 5.8$ & NS \\
\hline Muscle mass $\mathrm{kg}$ & $45.9 \pm 6.6$ & & $45.1 \pm 6.1$ & NS \\
\hline Muscle mass $\mathrm{kg}$ after 6 weeks & $42.9 \pm 5.1$ & NS & $46.6 \pm 6.5$ & \\
\hline Total body water TBW kg & $48.7 \pm 4.8$ & & $47.4 \pm 5.7$ & \\
\hline Total body water TBW kg after 6 weeks & $45.7 \pm 4.9$ & NS & $47.0 \pm 4.0$ & NS \\
\hline Extracellular water EW kg & $20.7 \pm 3.1$ & & $20.0 \pm 2.7$ & \\
\hline Extracellular water EW kg after 6 weeks & $19.6 \pm 3.0$ & $P<0,025$ & $18.7 \pm 1.8$ & NS \\
\hline Intracellular water IW kg & $28.0 \pm 3.7$ & & $27.4 \pm 3.5$ & \\
\hline Intracellular water IW kg after 6 weeks & $26.2 \pm 2.8$ & NS & $28.3 \pm 3.8$ & NS \\
\hline
\end{tabular}

In patients who followed the CRON diet for the period of 6 weeks, a statistically significant decrease of extracellular water was observed. The participants who used the Mediterranean diet, a statistically significant reduction was the one regarding the thickness of the skinfold over the iliac crest and the reduction of waist line. In both groups the reduction of BMI was statistically significant, with this reduction being larger in the CRON diet (-1.5 vs $-0,6)$.

Tahle 5. Changes in patients from both groups, those who lost between $1.4-2.4 \mathrm{~kg}$

\begin{tabular}{|c|c|c|c|c|}
\hline \multirow{2}{*}{ Intervention } & \multicolumn{2}{|c|}{ CRON } & \multicolumn{2}{|c|}{ Mediterranean } \\
\hline & Average \pm SD & $\mathrm{P}$ & Average \pm SD & $\mathrm{P}$ \\
\hline 1 & 2 & 3 & 4 & 5 \\
\hline BMI & $30.0 \pm 4.2$ & & $30.7 \pm 4.3$ & \\
\hline BMl after 6 weeks & $28.3 \pm 3.9$ & $p<0.015$ & $29.7 \pm 4.0$ & $P<0.05$ \\
\hline Thickness of the skinfold over the triceps & $16.0 \pm 5.9$ & & $13.4 \pm 7.5$ & \\
\hline Thickness of the skinfold over triceps after 6 weeks & $13.9 \pm 7.7$ & NS & $13.5 \pm 6.0$ & NS \\
\hline Thickness of the skinfold over biceps & $15.4 \pm 6.3$ & & $12.1 \pm 4.9$ & \\
\hline Thickness of the skinfold over biceps after 6 weeks & $15.9 \pm 5.4$ & NS & $14.7 \pm 5.1$ & NS \\
\hline Thickness of the skinfold below the shoulder blade & $25.4 \pm 6.5$ & & $24.9 \pm 8.2$ & \\
\hline Thickness of the skinfold below shoulder blade after 6 weeks & $24.0 \pm 6.5$ & NS & $23.1 \pm 7.5$ & NS \\
\hline Thickness of the skinfold over the hip & $23.9 \pm 8.5$ & & $24.1 \pm 7.8$ & \\
\hline Thickness of the skinfold over hip after 6 weeks & $21.9 \pm 5.7$ & NS & $20.4 \pm 5.4$ & NS \\
\hline Upper arm circumference & $35.1 \pm 2.4$ & & $37.0 \pm 4.1$ & \\
\hline Upper arm circumference after 6 weeks & $34.7 \pm 1.8$ & NS & $36.1 \pm 4.2$ & NS \\
\hline
\end{tabular}




\begin{tabular}{|c|c|c|c|c|}
\hline 1 & 2 & 3 & 4 & 5 \\
\hline Waist circumference & $101.3 \pm 8.6$ & & $100.8 \pm 10.6$ & \\
\hline Waist circumference after 6 weeks & $98.9 \pm 8.2$ & NS & $96.7 \pm 10.0$ & $P<0.05$ \\
\hline Hip circumference & $98.0 \pm 28.4$ & & $103.7 \pm 6.0$ & \\
\hline Hip circumference after 6 weeks & $105.2 \pm 4.4$ & $P<0.05$ & $95.7 \pm 14.7$ & NS \\
\hline Fat mass $\mathrm{kg}$ & $31.9 \pm 10.2$ & & $35.8 \pm 6.5$ & \\
\hline Fat mass $\mathrm{kg}$ after 6 weeks & $32.9 \pm 6.7$ & NS & $33.0 \pm 9.5$ & NS \\
\hline Fat mass $\%$ & $31.6 \pm 8.1$ & & $34.9 \pm 3.2$ & \\
\hline Fat mass $\%$ after 6 weeks & $34.2 \pm 5.0$ & NS & $33.3 \pm 5.7$ & NS \\
\hline Lean body mass $\mathrm{kg}$ & $67.6 \pm 7.3$ & & $66.4 \pm 9.1$ & \\
\hline Lean body mass after 6 weeks & $63.0 \pm 7.9$ & $P<0.04$ & $64.7 \pm 7.0$ & NS \\
\hline BCM kg & $38.3 \pm 6.5$ & & $37.9 \pm 6.0$ & \\
\hline BCM kg after 6 weeks & $35.7 \pm 4.9$ & NS & $39.6 \pm 6.8$ & NS \\
\hline Muscle mass $\mathrm{kg}$ & $46.8 \pm 7.3$ & & $46.2 \pm 7.1$ & \\
\hline Muscle mass $\mathrm{kg}$ after 6 weeks & $43.6 \pm 5.7$ & NS & $47.8 \pm 7.8$ & NS \\
\hline Total body water TBW kg & $50.3 \pm 4.2$ & & $49.1 \pm 6.2$ & \\
\hline Total body water TBW kg after 6 weeks & $47.0 \pm 4.9$ & $P<0.03$ & $47.9 \pm 4.7$ & NS \\
\hline Extracellular water EW kg & $21.7 \pm 2.5$ & & $20.9 \pm 2.8$ & \\
\hline Extracellular water EW $\mathrm{kg}$ after 6 weeks & $20.3 \pm 3.0$ & $P<0.025$ & $18.8 \pm 1.9$ & $P<0,025$ \\
\hline Intracellular water IW kg & $28.6 \pm 4.0$ & & $28.1 \pm 4.0$ & \\
\hline Intracellular water IW kg after 6 weeks & $26.7 \pm 3.0$ & NS & $29.1 \pm 4.3$ & NS \\
\hline
\end{tabular}

Among the patients from the CRON group, a statistically significant observation was that regarding an increase of the hip circumference, as well as a decrease of body's lean mass, total body water content and extracellular water. Among those who followed Mediterranean diet, statistically significant were: the reduction of fat mass, reduction of waist circumference and of extracellular water. In both groups, a reduction of BMI was statistically significant (reduction by $1.7 \mathrm{~kg} / \mathrm{m}^{2}$ vs $1.0 \mathrm{~kg} / \mathrm{m}^{2}$ ).

Table 6. Changes in patients from both groups, those who lost over $2.4 \mathrm{~kg}$

\begin{tabular}{|c|c|c|c|c|}
\hline \multirow{2}{*}{ Intervention } & \multicolumn{2}{|c|}{ CRON } & \multicolumn{2}{|c|}{ Mediterranean } \\
\hline & Average $\pm \mathrm{SD}$ & $\mathrm{P}$ & Average \pm SD & $\mathrm{P}$ \\
\hline 1 & 2 & 3 & 4 & 5 \\
\hline BMI & $32.0 \pm 5.0$ & & $30.0 \pm 4.2$ & \\
\hline BMI after 6 weeks & $31.0 \pm 5.0$ & $p<0.02$ & $28.3 \pm 3.9$ & $P<0.015$ \\
\hline Thickness of the skinfold over the triceps & $16.2 \pm 6.5$ & & $13.5 \pm 8.1$ & \\
\hline Thickness of the skinfold over triceps after 6 weeks & $16.0 \pm 6.6$ & NS & $13.9 \pm 6.3$ & NS \\
\hline Thickness of the skinfold over biceps & $16.0 \pm 5.6$ & & $11.9 \pm 5.3$ & \\
\hline Thickness of the skinfold over biceps after 6 weeks & $16.0 \pm 6.1$ & NS & $15.1 \pm 5.4$ & NS \\
\hline Thickness of the skinfold below the shoulder blade & $26.5 \pm 6.8$ & & $26.5 \pm 7.3$ & \\
\hline Thickness of the skinfold below shoulder blade after 6 weeks & $25.4 \pm 6.4$ & NS & $24.4 \pm 7.2$ & NS \\
\hline Thickness of the skinfold over the hip & $25.2 \pm 9.4$ & & $25.6 \pm 7.2$ & \\
\hline Thickness of the skinfold over hip after 6 weeks & $21.7 \pm 6.5$ & $P<0.03$ & $21.6 \pm 4.4$ & NS \\
\hline Upper arm circumference & $36.0 \pm 1.9$ & & $37.7 \pm 3.9$ & \\
\hline Upper arm circumference after 6 weeks & $35.1 \pm 1.9$ & NS & $36.8 \pm 4.1$ & NS \\
\hline Waist circumference & $103.1 \pm 9.0$ & & $102.0 \pm 11.0$ & \\
\hline Waist circumference after 6 weeks & $100.3 \pm 8.2$ & $P<0.03$ & $97.7 \pm 10.3$ & NS \\
\hline
\end{tabular}




\begin{tabular}{|c|c|c|c|c|}
\hline 1 & 2 & 3 & 4 & 5 \\
\hline Hip circumference & $96.5 \pm 32.6$ & & $103.9 \pm 6.4$ & \\
\hline Hip circumference after 6 weeks & $105.6 \pm 4.8$ & $P<0.015$ & $95.1 \pm 15.8$ & NS \\
\hline Fat mass $\mathrm{kg}$ & $35.7 \pm 7.2$ & & $35.9 \pm 7.0$ & \\
\hline Fat mass $\mathrm{kg}$ after 6 weeks & $34.6 \pm 6.5$ & NS & $33.3 \pm 10.2$ & $P<0.03$ \\
\hline Fat mass $\%$ & $34.4 \pm 5.4$ & & $34.5 \pm 3.2$ & \\
\hline Fat mass $\%$ after 6 weeks & $34.7 \pm 5.4$ & NS & $33.1 \pm 6.1$ & NS \\
\hline Lean body mass $\mathrm{kg}$ & $67.9 \pm 7.5$ & & $67.7 \pm 9.0$ & \\
\hline Lean body mass after 6 weeks & $65.0 \pm 7.8$ & $P<0.02$ & $65.7 \pm 6.9$ & NS \\
\hline BCM kg & $37.1 \pm 5.2$ & & $39.2 \pm 5.2$ & \\
\hline BCM kg after 6 weeks & $36.1 \pm 5.4$ & NS & $40.9 \pm 6.1$ & NS \\
\hline Muscle mass $\mathrm{kg}$ & $45.6 \pm 6.0$ & & $47.6 \pm 6.3$ & \\
\hline Muscle mass $\mathrm{kg}$ after 6 weeks & $44.3 \pm 6.2$ & NS & $49.2 \pm 7.0$ & NS \\
\hline Total body water TBW kg & $50.8 \pm 3.8$ & & $49.6 \pm 6.6$ & \\
\hline Total body water TBW kg after 6 weeks & $48.7 \pm 4.1$ & $P<0.02$ & $48.1 \pm 5.0$ & NS \\
\hline Extracellular water EW kg & $22.8 \pm 1.4$ & & $20.8 \pm 3.0$ & \\
\hline Extracellular water EW kg after 6 weeks & $21.5 \pm 2.1$ & $P<0.05$ & $18.4 \pm 1.7$ & $P<0.03$ \\
\hline Intracellular water IW kg & $28.0 \pm 3.0$ & & $28.8 \pm 3.8$ & \\
\hline Intracellular water IW kg after 6 weeks & $27.2 \pm 3.1$ & NS & $29.7 \pm 4.2$ & NS \\
\hline
\end{tabular}

In the sub-group of participants who lost $>2.4 \mathrm{~kg}$ of body weight, the highest number of statistical significances was observed. In the CRON group, a statistically significant reduction of the thickness of skinfold over the iliac crest was observed, as well as the reduction of waist line, and an increase of hip circumference, and a decrease of the lean body mass. There was also a statistically significant reduction of total body water content and of extracellular water. In the Mediterranean group, a statistically significant change was the reduction of fat mass and of extracellular water. In both groups, a reduction of BMI was statistically significant (reduction by $1.0 \mathrm{~kg} / \mathrm{m}^{2} \mathrm{vs} 1.7 \mathrm{~kg} / \mathrm{m}^{2}$ ).

Table 7. Changes in control group

\begin{tabular}{|c|c|c|}
\hline \multirow{2}{*}{ Intervention } & \multicolumn{2}{|c|}{ Control group } \\
\hline & Average $\pm \mathrm{SD}$ & $P$ \\
\hline 1 & 2 & 3 \\
\hline Thickness of the skinfold over the triceps & $10.6 \pm 4.3$ & \\
\hline Thickness of the skinfold over triceps after 6 weeks & $11.7 \pm 5.3$ & NS \\
\hline Thickness of the skinfold over biceps & $6.6 \pm 2.2$ & \\
\hline Thickness of the skinfold over biceps after 6 weeks & $7.4 \pm 4.8$ & NS \\
\hline Thickness of the skinfold below the shoulder blade & $15.3 \pm 4.6$ & \\
\hline Thickness of the skinfold below shoulder blade after 6 weeks & $15.5 \pm 4.7$ & NS \\
\hline Thickness of the skinfold over the hip & $12.5 \pm 2.3$ & \\
\hline Thickness of the skinfold over hip after 6 weeks & $17.2 \pm 7.3$ & NS \\
\hline Upper arm circumference & $32.5 \pm 1.5$ & \\
\hline Upper arm circumference after 6 weeks & $32.3 \pm 2.8$ & NS \\
\hline Waist circumference & $87.3 \pm 7.2$ & \\
\hline Waist circumference after 6 weeks & $87.6 \pm 7.4$ & $\mathrm{P}<0.03$ \\
\hline Hip circumference & $90.1 \pm 20.0$ & \\
\hline Hip circumference after 6 weeks & $94.9 \pm 4.0$ & $P<0.015$ \\
\hline
\end{tabular}




\begin{tabular}{|c|c|c|}
\hline 1 & 2 & 3 \\
\hline Fat mass $\mathrm{kg}$ & $20.8 \pm 5.4$ & \\
\hline Fat mass $\mathrm{kg}$ after 6 weeks & $23.1 \pm 7.9$ & NS \\
\hline Fat mass $\%$ & $26.0 \pm 4.3$ & NS \\
\hline Fat mass $\%$ after 6 weeks & $28.5 \pm 7.2$ & \\
\hline Lean body mass $\mathrm{kg}$ & $58.6 \pm 5.0$ & \\
\hline Lean body mass after 6 weeks & $56.7 \pm 4.6$ & $P<0.02$ \\
\hline BCM kg & $34.0 \pm 3.4$ & \\
\hline BCM kg after 6 weeks & $34.0 \pm 4.6$ & NS \\
\hline Muscle mass kg & $41.4 \pm 4.0$ & \\
\hline Muscle mass $\mathrm{kg}$ after 6 weeks & $41.2 \pm 5.2$ & NS \\
\hline Total body water TBW kg & $42.9 \pm 3.6$ & \\
\hline Total body water TBW kg after 6 weeks & $41.5 \pm 3.4$ & $P<0.02$ \\
\hline Extracellular water EW kg & $17.9 \pm 1.5$ & \\
\hline Extracellular water EW kg after 6 weeks & $16.6 \pm 1.0$ & $P<0.05$ \\
\hline Intracellular water IW kg & $25.9 \pm 2.2$ & \\
\hline Intracellular water IW kg after 6 weeks & $24.9 \pm 3.1$ & NS \\
\hline
\end{tabular}

Among the members of the control group $(n=28)$ after 6 weeks of unregulated consumption there were increases of thickness of skinfolds, increase of waist and hip circumference, and fat tissue content. The decrease in lean body mass was observed, the same for water content. Statistical significance was not established for any of these changes.

\section{Discussion}

According to A. Tsigos studies (2009), 10-25\% of Europeans are obese, while the number of overweight and obese people has grown over the last 10 years by $10-40 \%$. This data corresponds with the results obtained from the present study. The largest percentage of men taking part in the study had BMI indicating obesity (57\% and 56\%), and only $25 \%$ and $22 \%$ had their BMI in the normal range $\left(20.0-24,99 \mathrm{~kg} / \mathrm{m}^{2}\right)$. This proves that in the group of former athletes, the problem of being overweight and obese is widespread. Admittedly, none of the participants of the study had obesity $\mathrm{II}^{\circ}$, however, $4 \%$ had obesity $\mathrm{II}^{\circ}$, which significantly increases the risk of diet-related diseases. Similar results were obtained by Arliani et al. (2014), who established overweight in $78 \%$ and obesity in $4 \%$ of footballers. Similar results were also presented by Marquet et al. (2013), who observed that $35 \%$ of examined athletes were overweight, while $3 \%$ - obese.

Visceral obesity is the most dangerous distribution of fat tissue in the body. One of the simplest and quickest ways to estimate the amount of visceral fat is to measure waist circumference. The average waist circumference of the men examined was $94.0 \mathrm{~cm}$ in the CRON diet group and $91.7 \mathrm{~cm}$ in the Mediterranean diet group. If recommendations of the International Diabetes Federation are considered, according to which abdominal obesity in men starts as early as at the waist line of $94 \mathrm{~cm}$, it can be observed that the CRON diet patients had a border-line value for waist circumference. Adding to that the percentage amounts of fat tissue which were $28.91 \%$ and $28.13 \%$, it can be stated that the average content of fat tissue in both groups indicated obesity (Pi-Sunyer, 2000). These results confirm the observation that an athlete ending his sporting career often does not differ from his peer who did not actively pursue sport in his earlier life. 
Despite having done sport in the past and having led a healthy lifestyle, after the end of their career, the occurrence of excessive weight and obesity is similar for the former athletes as for their peers who never actively pursued sport. It is common knowledge that the occurrence of excessive weight, obesity and increased proportion of fat tissue in the body are all related to the increased risks of developing diet-related diseases. It is estimated that for men up to the age of 65 whose BMI is $25.0-28.9 \mathrm{~kg} / \mathrm{m}^{2}$, the risk of ischemic heart disease increases by $72 \%$ (Szymocha, Bryła, Maniecka-Bryła, 2009). It is, therefore, important to take care of the athletes health not only during their career, but also after its completion. Usually, it is after the end of their career that, in combination with the aging process, undesirable changes in the body appear.

A change in parameters was observed in each of the sub-groups after the intervention. In the subgroup, which reduced their body weight by up to $1.4 \mathrm{~kg}$, there were more statistically significant changes observed in the Mediterranean group. In the CRON group, there were significant changes in the reduction of $\mathrm{BMI}$ and the proportion of extracellular water. In the group of the Mediterranean diet, more parameters were observed which proved changes in the fat tissue: BMI reduction, hip skinfold reduction, and smaller waist line. This attests to the fact that in this group, the Mediterranean diet had larger impact on the reduction of fat tissue.

In the sub-group which lost 1.5-2.4 kg similar effects of both diets were observed. Both the Mediterranean diet and the CRON diet resulted in BMI reduction. In the Mediterranean diet group, an additional observation was made regarding the reduction of fat mass and of waist circumference. The CRON diet resulted in the reduction of lean body mass, but this change was brought about by the reduction of water.

The most significant changes were observed in the sub-group which lost $>2.4 \mathrm{~kg}$. From the nutritional point of view, the most important change was the reduction of BMI which was observed both in the CRON group and the Mediterranean group. The CRON diet also caused a reduction of the skinfold over the hip and a decrease of waist circumference, whereas the Mediterranean diet - a reduction of fat mass. The only undesirable change was the reduction of lean body mass. If, however, the reduction of water is taken into account, it can be stated that the reduction of lean body mass was caused by these changes.

The existing literature lacks in the studies comparing the impacts of the CRON diet and the Mediterranean diet on the body composition. However, in few, similar research studies, similar results have been produced. The study by Racette et al. (2006) demonstrated that the people following a $20 \%$ caloric restriction of the period of one year were observed to lose the fat tissue located around waist (body weight reduction by $8.0 \pm 0.9 \mathrm{~kg}$ and the reduction of fat tissue by $6.2 \pm 1.2$ ). Similarly, Redman et al. (2008) demonstrated that men following a $25 \%$ caloric restriction regimen for the period of 6 months were observed to reduce fat tissue by $5.8 \pm 1.3 \mathrm{~kg}$ and to reduce visceral fat tissue by $1.4 \pm 0.2 \mathrm{~kg}$. That diet, however, had more desirable effect when combined with physical activity. A positive impact of the Mediterranean diet was, in turn, demonstrated by Shai et al. (2008), who compared the Mediterranean diet, low fat diet and low carbohydrate diet, and found that men who followed the Mediterranean diet for 24 months lost $4 \mathrm{~kg}$ of body weight and their BMl dropped by $1.5 \pm 2.2$ and the waist circumference by $3.5 \pm 5.1 \mathrm{~cm}$. In this study, the largest impact was from the low carbohydrate diet.

In summary, it can be stated that both diets followed for the period of 6 weeks brought about similar, desirable changes to the body composition of former athletes. They primarily caused a reduction of BMI and a decrease of waist circumference - important indicators of risks of diet-related diseases. This observation is important, because according to the WHO (World Health Organization), body weight of an average human will continue rising over the coming 10 years (Szymocha et al., 2009). Therefore, it is of such great importance to find ways of preventing the 
risks of excessive weight and obesity for middle-aged persons. One of such ways is the application of a diet based on mild caloric restriction or a Mediterranean diet.

\section{Conclusions}

Both the diet based on mild caloric restriction and the Mediterranean diet had positive effect on the change of the former athlete's body parameters after the 6 -week long dietary intervention.

Both diets which were being tested changed the body composition of the athletes who ended their careers in a similar way.

Mild caloric restriction diet and Mediterranean diet may both be recommended for people after ending sporting careers.

It seems that by implementing the diets as an algorithm after the end of a sporting career, it will be possible to reduce the occurrence of excessive weight or obesity in the group of athletes, which will affect their health in a positive way.

\section{Acknowledgments}

The work is supported by grant NCN KB-0012/53/11.

\section{References}

Arliani, G., Lara, P., Astur, D., Cohen, M., Goncalves, J., Ferretti, M. (2014). Impact of sports on health of former professional soccer players in Brazil. Acta Ortopedica Brasileira, 22 (4), 188-190.

Batista, C., Soares, J. (2013). Are former athletes more protected against metabolic syndrome? Journal of Cardiology, 61, 440-445.

Heilbronn, L., Ravussin, E. (2003). Calorie restriction and aging: review of the literature and implications for studies in humans. The American Journal of Clinical Nutrition, 78, 361-369.

Jaskólski, A., Jaskólska, A. (2005). Zmiany fizjologiczne u osób w wieku średnim i starszym a zdolność do wykonywania wysiłku fizycznego. In: Jaskólski A., Jaskólska A. Podstawy fizjologii wysiłku fizycznego z zarysem fizjologii człowieka (pp. 375-400). Wrocław: Wydawnictwo AWF.

Kerr, Z., DeFreese, J., Marshall, S. (2014). Current physical and mental health of former collegiate athletes. Orthopaedic Journal of Sports Medicine, 2 (8). DOI: 10.1177/2325967114544107.

Lorenzini, A. (2014). How much should we weigh for a long and health life span? The need to reconcile caloric restriction versus longevity with body mass index versus morality data. Frontiers in Endocrinology, 5 (121). DOI: 10.3389/fendo.2014.00121.

Marquet, L., Brown, M., Tafflet, M., Nassif, H., Mouraby, R., Bourhaleb, S., Desgorces, F. (2013). No effect of weight cycling on the postcareer BMI of weight class elite athletes. BMC Public Health. DOI: 10.1186/1471-2458-13-510.

O'Kane, J., Teitz, C., Fontana, S., Lind, B. (2002). Prevalence of obesity in adult population of former college rowers. The Journal of the American Board of Family Practise, 15 (6), 451-456.

Pi-Sunye, F. (2000). Obesity: criteria and classification. Proceedings of the Nutrition Society, 59 (4), 505-509.

Pihl, E., Jürimäe, T. (2001). Relationships between body weight change and cardiovascular disease risk factors in male former athletes. International Journal of Obesity and Related Metabolic Disorders, 25 (7), 1057-1062.

Przysławski, J. (2007). Dieta śródziemnmorska. In: Gertig, H., Przysławski, J. (eds.), Bromatologia, zarys nauki o żywności i żywieniu (pp. 435-440). Warszawa: Wydawnictwo Lekarskie PZWL.

Racette, S., Weiss, E., Villareal, D., Arif, H., Stegar-May, K., Schechtman, K. (2006). One year of caloric restriction in humans: feasibility and effects on body composition and abdominal adipose tissue. The Journals of Gerontology Series: A Biological Sciences and Medical Sciences, 61 (9), 943-950.

Redman, L., Rood, J., Anton, S., Champagne, C., Smith, S., Ravussin, E. (2008). Calorie restriction and bone health in young, overweight individuals. Archives of Internal Medicine, 168 (17), 1859-1866. 
Shai, I., Schwarzfuchs, D., Henkin, Y., Shahar, D., Witkow, S., Greenberg, I. (2008). Weight loss with a low-carbohydrate, Mediterranean or low-fat diet. The New England Journal of Medicine, 359 (3), 229-241.

Sławecki, K. (2012). Aktywność fizyczna mężczyzn oceniana za pomocą Międzynarodowego Kwestionariusza Aktywności Fizycznej IPAQ - wersja długa. Antropomotoryka, 59, 57-66.

Szczawińska, I., Ponikowska, I., Chojnowski, Grabowska, J. (2006). Wybrane wskaźniki antropometryczne u otyłych byłych sportowców. Balneologia Polska, 2, 106-110.

Szymocha, M., Bryła, M., Maniecka-Bryła, I. (2009). Epidemia otyłości w XXI wieku. Zdrowie Publiczne, 119 (2), $207-212$.

Tsigos, C., Halner, V., Basdevant, A., Finer, N., Fried, M., Mathus-Vliegen, E. (2009). Postępowanie w otyłości dorosłych: europejski wytyczne dla praktyki klinicznej. Endokrynologia, Otyłość i Zaburzenia Przemiany Materii, 5 (3), 87-98.

Cite this article aS: Czerwińska, M., Hołowko, J., Maciejewska, D., Wysokiński, P., Ficek, K., Wilk, P., Stachowska, E. (2016). Caloric Restriction Diet (CR Diet) or Mediterranean Diet (MD) - Which is the Best Choice for Former Athletes? Central European Journal of Sport Sciences and Medicine, 13 (1), 23-35. DOI: 10.18276/cej.2016.1-03. 
